\title{
Mutual Fund Performance: Evidence from India
}

\author{
Mahfooz Alam
}

\begin{abstract}
We empirically examine fund managers' stock selection and market timing ability using various risk-adjusted measures such as CAPM and multifactor models of FamaFrench (1993) and Carhart (1997) to gauge mutual fund performance in India. The sample consists of 183 actively managed equity-oriented funds and covers the period from April 2000 to March 2018. The study, on the whole, documents some evidence of positive and significant stock selection ability but fails to yield any notable evidence of market timing ability of fund managers. Our results are robust according to various riskadjusted performance evaluation techniques, sub-period analysis, excluding the crisis period and at the individual fund level. The findings of our study are in line with the previous studies that report limited selectivity skill and market timing ability among fund managers. The main implication of the study is that active portfolio management may not be very rewarding in comparison to a passive investment strategy.
\end{abstract}

Keywords: Indian mutual funds, market timing, performance evaluation, stock selection skills.

\section{INTRODUCTION}

Mutual funds as an investment avenue havegained popularity among investorsin a fast-growing economy like India.According to the Association of Mutual Funds in India (AMFI) data, theassetsunder management (AUM) in the mutual fund industryhave grown from 9.16 trillion Indian Rupees (INR) as on $28^{\text {th }}$ February,2014 to 23.16 trillion INR as on $28^{\text {th }}$ February 2019 which constitutes more than $2 \frac{1}{2}$ fold increase in a span of 5 years. The investors want to put their money in safe hands in general and actively managed mutual funds in particular, even when the index funds are available to them at a much cheaper rate, in anticipation to "beat the market" instead of merely "riding with themarket." In the wake of this, the role of fund managers has become crucial as the performance evaluation of mutual fund assumes significance. The performance of the mutual fund is measured usingdichotomous skills: stock selection and market timing ability of fund managers. Stock selection is the skill of fund managers to choose undervalued/overvalued assets. If the fund managers possess stock-picking skills, they will yield a higher risk-adjusted return relative to a benchmark. Market timing ability, also known as macro-forecasting, is the forecasting skill of the portfolio managers to predict the future stock market movements byrebalancing the total risk composition of their portfolios.Different researchers (Jensen, 1968; Elton et al., 1996; Zheng, 1999; Feng et al., 2014) have investigated the portfolio stock selection skill of

Manuscript published on November 30, 2019.

* Correspondence Author

Mahfooz Alam*, PhD, Finance in the department of Business Administration, Faculty of Management Studies and Research, Aligarh Muslim University, India.

(C) The Authors. Published by Blue Eyes Intelligence Engineering and Sciences Publication (BEIESP). This is an open access article under the CC-BY-NC-ND license http://creativecommons.org/licenses/by-nc-nd/4.0/ the fund managers on the risk-adjusted basis. Several studies (Treynor and Mazuy, 1966; Henriksson and Merton, 1981; Henriksson 1984; Chang and Lewellen 1984; Grinblatt and Titman, 1989; Lee and Rahman, 1990; Ferson and Schadt, 1996; Jiang, 2003; Jiang et al., 2007; Cuthbertson et al.,2012; Angelidis, 2013; Bodson et al., 2013; and Ferson and Mo, 2016; Yi and He, 2016)have explored the market timing ability of the fund managers.The majority of thesestudies report little evidence of timing ability among fund managers. However, (Bollen andBusse, 2001; Jiang et al., 2007) on the contrary, found that mutual fundmanagers exhibit significant timing ability and are able to outguess the market over a long period of time using daily frequency data. In the Indian scenario, there exists a paucity of literature on the performance evaluation of the mutual fund. The major studies in the Indian context include those by Jayadev, 1998;Roy and Deb, 2004; Deb et al., 2007; Kundu, 2009; Agrawal, 2011; Kumar, 2012; Dhar and Mandal, 2014.These studies suffer from various limitations.Firstly,the majorityof studies have employed CAPM as a benchmark for performance evaluation. Moreover, they are conducted usinga smaller sample size thatspans over a short time period.The present study attempts to fill the empirical void in mutual fund performance evaluation usingmultifactor measures such as Fama-French (1993) and Carhart (1997) models to examine the presence of stock selection and market timingskills among the mutual fund managers, utilizing comparatively larger sample over a longer period fromApril 2000 to March 2018. The empirical analysis in our paper documents some key findings. The Indian fund managers provide positive alpha coefficients (65 per cent) over the study period measured using single and multifactor models. However, only 39 funds (21 per cent of the total sample) exhibit positive and significant alpha depicting stock selection ability at even $10 \%$ significance level. Secondly, the result indicates that the Indian fund managers lack market timing ability and even displayperverse timing ability as indicated by negative market timing coefficients. Our findings are in line with several previous studies(Treynor andMazuy, 1966; Henrikson, 1984; Lee and Rehman, 1990; Jiang, 2003; Cuthbertson et al., 2012; Oliviera et al., 2019). The remainder of the paper is structured as follows:the performance evaluation techniques proposed in the financial literature for stock selection and market timing ability of mutual fund managers are reviewed under Section 2. In Section 3, the sample data and methodology used in our study are described. 


\section{Mutual Fund Performance: Evidence from India}

Theempirical test results are described in Section 4 . Lastly, Section 5 discusses and highlights the main conclusion of the study.

\section{LITERATURE REVIEW}

Traditional studies on performance evaluation are based on a linear parameter of risk and return (Sharpe, 1966; Treynor, 1965). Initially, Jensen (1968) had focused on stock picking ability of fund managers, by incorporating the selectivity skill in his study measured through alpha by utilizing CAPM and reported underperformance of the fund managers. Fama (1972), on the other hand, was among the first to decompose the performance of fund managers based on "selectivity and market timing”. Several notable studies such as (Kon, 1983; Ippolito, 1989; Grinblatt and Titman, 1989; Malkiel, 1995; Elton et al., 1996, Zheng, 1999; Fama and French, 2010; Neto, 2014) empirically examine the stock selection skill of the fund managers and reported mixed conclusions of stock selectivity skills among the fund managers. Market timing ability of the fund managers' is extensively investigated in the financial literature to gauge fund performance. The theoretical model to capture the fund manager's market timing skills was formulated by Treynor and Mazuy (1966, hereafter, TM). They analyzed 57 open-ended mutual funds and the study concludes that investment managers do not exhibit any ability in outperforming the market returns. Later, Henriksson and Merton (1981, hereafter, HM) and Henriksson (1984) evaluated the market timing of fund managers by developing a model. Henriksson (1984) adapted the parametric and nonparametric test in his study that revealed that actively managed funds lacked any timing ability among fund managers and an inverse relationship is found between the selection and timing of funds. Since then, many researchers had conducted studies in different markets employing various timing models to outline the presence of timing ability (Chang and Lewellen 1984; Grinblatt and Titman, 1989; Lee and Rahman, 1990; Ferson and Schadt, 1996; Jiang et al., 2007; Cuthbertson et al., 2012; Angelidis, 2013; Bodson et al., 2013; Ferson and Mo, 2016; Yi and He, 2016; Agarwal and Pradhan, 2018; Oliviera et al., 2019) and report inconclusive evidence.The majority of these studies on mutual funds have been conducted in developed countries.In comparison, the studies on fund managers' performance in emerging markets are limited. Using themarket timing models of TM and HM, Phillipas (2002) analyzed the Greek market and reports statistically negative significant skills among the fund managers. Similarly, Romacho and Cortez (2006) found the negative stock selection and market timing coefficients in Portuguese domestic funds. Unal and Tan (2015)examined the Polish equity fund managers and foundpositive and insignificant selection and market timing ability.Chen et al. (2013) evaluated Chinese mutual funds' performance and reported that the fund managers possess selective ability to earn excess returns, but do not exhibit market timing ability.
Similarly, Yi et al. (2018) examinedthe market timing abilities of Chinese equity mutual funds and reported that only growth funds show return timing skills. On the contrary, Bollen and Busse (2001) andJiang et al. (2007) provide evidence ofsuccessful market timing ability.Several other studies have traced down the evidence of outperformers of fund managers with persistence (Grinblatt and Titman, 1992; Hendricks, Patel and Zeckhauser, 1993; Carhart, 1997).In contrast with the results reported in the developed and several other developing economies, the Indianstudies evaluating the performance ofmutual funds reported positive and significant selection ability (Gupta and Sehgal, 1998; Roy and Deb, 2004; Ahmad and Samajpati, 2010; Panda et al., 2015). Deb et al. (2007) analyzed the skills of fund managers using both unconditional and conditional approaches and conclude that fund managers exhibit stock selection skills but lack market timing abilities. The empirical evidence on market timing ability in India, however, is in agreement with the previous studies conducted indeveloped nations such as US and UK as well as other emerging markets, reporting negative or absence of any market timing ability among Indian fund managers (Tripathy,2006;Kumar,2012; Dhar and Mandal,2014; and Panda et al.,2015), with fewer evidence of market timing as well (Ahmad and Samajpati, 2010; Agarwal and Pradhan, 2018).

\section{DATA AND METHODOLOGY}

\section{a. Data}

We obtain the sample data from Association of Mutual Funds in India (AMFI) database. The AMFI database provides fund net asset values (NAV), scheme details, assets under management (AUM), their classification and other fund characteristics of all India based mutual funds. Our sample consists of actively manageopen-ended growth option equity schemes.We haveexcluded from our sample the funds that cease to exist. The sample is further purged to eliminate the funds with less than 5 years ofdata (60 observations) in the study period (Fama and French, 2010; Barras, Scaillet and Wermers, 2010).The final sample for our study comprises183 equity funds having monthly observations. We bifurcate our data into two equal subperiods to check for robustness. For sub-period I (April 2000 to March 2009), the number of mutual fund schemesis 144 and for sub-period II (April 2009 to March 2018), it is 183. We calculated each fund monthly returns from NAV's and deducted it from the risk-free rate (RFR) to arrive at the monthly fund excess return. We use the 91 days treasury bills as the risk-free rate, issued by India's central bank, the Reserve Bank of India (RBI). The stock index proxied as the market is S\&P BSE 500. We calculated the excess market return(MKT) deducting the risk-free rate. 
The definition of various variables and equity-oriented mutual funds used in our study are presented in Appendix A. The additional data of stock prices, market capitalization, book-to-market ratio required for the calculation of size (SMB), value (HML) and momentum (WML) factors are collected from CMIE ProwessIQ database. These factors have been formed usingthe methodology proposed by Fama and French (1993). Thedetailed description regarding the formation of size, value and momentum factors is provided in Appendix B.Table 1 provides the descriptive summary statistics of the mutual fund's data for the entire sample period, two sub-periods as well as various factor variables. The table reports average monthly returns, standard deviation, minimum, maximum, skewness and kurtosis of mutual funds for the period from April 2000 to March 2018. The monthly mean returns in sub-period 2 are higher at 1.10 per cent with a lower standard deviation of 5.42 per cent, in comparison with the mean return of sub-period 1 at 0.74 per cent, having a highest standard deviation of 7.56 per cent. The monthly excess mean returns for the entire sample of Indian mutual funds is $0.92 \%$ (approx. $11.04 \%$ per annum), having a standard deviation of $6.56 \%$. Panel B in Table 3.3 exhibits the summary of the factor variables. The monthly excess mean market return (MKT) is $0.76 \%$, and a standard deviation at $7.29 \%$, from 2000 to 2018. The average monthly return of size factor is $0.99 \%$, while the value and momentum factors show returns of $1.02 \%$ and $1.01 \%$, respectively. The table also reports 1st quartile, median and 3rd quartile of the data. Skewness and Kurtosis are used to check the normality of the data. The value of skewness and kurtosis of the factor variables show that the data series is normally distributed. The skewness values ranged from 0.79 to +1.51 , whereas the kurtosis values ranged from -0.52 to +7.58 . The majority of the variables shows skewness near zero indicating that the data follows the normal distribution. The negative skewness of the indices implies that the return distribution of indices has a higher probability of earning negative returns. Moreover, Panel A and B depictpositive kurtosis (moderately normally distributed), except for subperiod 2 in Panel A and WML in Panel B exhibits a high kurtosis (high peak and fat tails) twice the value of a normal distribution, but not alarming enough to need treatment.The table provides the summary statistics of the variables used in our empirical study. Panel A summarizes the average monthly excess returns of the equity funds (overall sample) as well as for sub-period 1 and sub-period 2. Panel B summarizes the factor variables including stock market index (MKT) excess return, SMB (size factor), HML(bookto-market value factor), and WML(momentum factor). We have at least 60 months of observation for each fund. The period of study is from April 2000 to March 2018.

Table 1 : Descriptive Statistics.

\begin{tabular}{|lccccccccr|}
\hline Variables & Mean & SD. & Min. & Max. & $\mathbf{2 5 \%}$ & Median & $\mathbf{7 5 \%}$ & Skew & Kurt \\
\hline \multicolumn{2}{l}{ Panel A: Summary of fund excess mean return (\%) } & & & & & & \\
\hline MF (Overall) & 0.92 & 6.56 & -24.62 & 30.88 & -2.56 & 1.37 & 4.77 & -0.20 & 2.58 \\
\hline Sub-period 1 & 0.74 & 7.56 & -24.62 & 15.57 & -4.60 & 2.08 & 6.16 & -0.79 & 0.55 \\
\hline Sub-period 2 & 1.10 & 5.42 & -10.47 & 30.88 & -1.65 & 0.64 & 3.62 & 1.51 & 7.58 \\
\hline Panel B: Summary of factor variables (\%) & & & & & & & \\
\hline RFR & 0.54 & 0.13 & 0.25 & 0.86 & 0.45 & 0.54 & 0.63 & -0.07 & -0.52 \\
\hline MKT & 0.76 & 7.29 & -27.74 & 33.07 & -3.25 & 1.16 & 5.22 & -0.19 & 2.68 \\
\hline SMB & 0.99 & 5.03 & -22.30 & 17.46 & -2.32 & 0.35 & 3.70 & 0.21 & 2.38 \\
\hline HML & 1.19 & 5.85 & -13.31 & 25.58 & -2.61 & 0.48 & 3.95 & 1.00 & 1.85 \\
\hline WML & 1.22 & 5.86 & -27.52 & 30.39 & -1.10 & 1.16 & 3.62 & -0.18 & 6.27 \\
\hline
\end{tabular}

SD stands for Standard Deviation, Min. stands for Although, there are no issues concerning multi-collinearity

Minimum, Max. for Maximum, Skew for Skewness and Kurt for Kurtosis.

Table 2 presents the correlation matrix. As shown in the table, there exists a low degree of collinearity among independent factor variables as the values lie below \pm 0.29 , depicting small correlation. The correlation between liquidity and volatility is moderately (negative) high. in regression.

The table presents the correlation pattern of the variables used in our empirical study. 
Table 2 Correlation matrix

\begin{tabular}{|lrcccr|}
\hline Variables & RFR & MKT & SMB & HML & WML \\
\hline RFR & 1 & & & \\
\hline MKT & -0.22 & 1 & & \\
\hline SMB & -0.18 & 0.17 & 1 & \\
\hline HML & -0.14 & 0.29 & 0.22 & 1 & \\
\hline WML & -0.05 & -0.08 & -0.14 & -0.11 & 1 \\
\hline
\end{tabular}

RFR: risk-free rate, MKT: market excess return, SMB: size, HML: value and WML: momentum factor.

\section{b. Methodology}

Theperformance evaluation of mutual fund managersisinvestigatedemploying several risk-adjustedperformance measurementssuch asJensen's (1968) measure based on the single-factor Capital Asset Pricing Model (CAPM), the three-factorFama-French(1993) model, and the four-factormodel ofCarhart (1997). All the models have been estimated using the standard OLS regression technique.

\section{i. Stock selection skills}

We estimated the performance of the fund manager using a single-factor modelof CAPM.

$$
R_{i t}-R_{f t}=\alpha_{i}+\beta_{1, \mathrm{t}}, \mathrm{MKT}_{\mathrm{t}}+\varepsilon_{i t}
$$

where, $R_{i t}-R_{f t}$ is the monthly market excess return over the risk-free rate in month $\mathrm{t}$. The coefficient $\alpha_{i}$ denotes performance of fund managers vis-à-vis stock selection skills. A positive and significant alpha denotes the presence of stock selection skill among the fund managers. We investigate the robustness of the results by measuring fund manager ability using multi-factor measures such as FamaFrench (1993) and Carhart's (1997) models.The multifactor models increase the significance of model fit as it explains the variations in return to a greater extent.Specifically, we first estimate, $\alpha_{\mathrm{i}}, \beta_{1}$, MKT, $\beta_{2}, \mathrm{SMB}$, and $\beta_{3}, \mathrm{HML}$ using Fama-French (1993)model in Eq. 2 and add the fourth explanatory variable as momentum in Fama-French (1993) to form a four-factor model of Carhart (1997) described in Eq. 3, as follows:

$$
R_{i t}-R_{f t}=\alpha_{i t}+\beta_{1, t} \mathrm{MKT}_{\mathrm{t}}+\beta_{2, t} \mathrm{SMB}_{\mathrm{t}}+\beta_{3, t} \mathrm{HML}_{\mathrm{t}}+\varepsilon_{i t}
$$

$R_{i t}-R_{f t}=\alpha_{i t}+\beta_{1, t} \mathrm{MKT}_{\mathrm{t}}+\beta_{2, t} \mathrm{SMB}_{\mathrm{t}}+\beta_{3, t} \mathrm{HML}_{\mathrm{t}},+\beta_{4, t}$ $\mathrm{WML}_{\mathrm{t}}+\varepsilon_{i t}$

where $R_{i t}-R_{f t}$ is the portfolio's abnormal return, MKT is benchmark'sexcess return, SMB measured as (small minus big) stocks between a portfolio, exhibits return on the size factor, HML measured as (high minus low) value stocks, mimics portfolio for value minus growth stockswhile in $\mathrm{Eq}$ (3) WML is the rate of return, measured as (winners minus losers) stocks during the previous year, denotes momentum factor respectively.

$\alpha_{i t}$ is the three-factor and four-factor alpha (intercept) in Eq (2) and (3), respectively. If the factor-alpha is positive and significant, it suggests that fund managers have stock selection skill considering size and value factor returns (Fama-French, 1993) and momentum factor returns (Carhart, 1997).

\section{ii. Market timing ability}

Thisstudyemploysthe commonly used classicalTMand HMmodelsto measure the market timing ability of Indian fund managers augmented with our baseline models of CAPM, three-factor Fama-French (1993) and the four-factor model ofCarhart's (1997). Specifically,

$R_{i t}-R_{f t}=\alpha_{i t}+\beta_{1, t} \mathrm{MKT}_{\mathrm{t}}+Y_{i t} \mathrm{MKT}_{\mathrm{t}}^{2}+\varepsilon_{i t}$
$R_{i t}-R_{f t}=\alpha_{i t}+\beta_{1, t} \mathrm{MKT}_{\mathrm{t}}+Y_{i t} \operatorname{Max}\left(\mathrm{MKT}_{\mathrm{t}}, 0\right)+\varepsilon_{i t}$

where, $R_{i t}-R_{f t}$ is the fund's excess return, $\alpha_{\mathrm{i}}$ exhibitstimeadjusted alpha referring stock-picking skill of fund managers, $\mathrm{MKT}_{\mathrm{t}}$ is the monthly market excess return in month t.The TM model captures the effect of market timing by adding a quadratic term to CAPM measure. Eq (4) depends linearly on market return while HM model, i.e. Eq (5) is a binary option Max $\left(\mathrm{MKT}_{\mathrm{t}}, 0\right)$ that relies on market response.In both the models, a positive and significant coefficient $\left(Y_{i t}>0\right)$ suggests successful market timers and vice-versa. The above two models can be extended to include the linear 'factor variables' of $\mathrm{SMB}_{\mathrm{t}}, \mathrm{HML}_{\mathrm{t}}$, and $\mathrm{WML}_{\mathrm{t}}$ that indicates the size, value and momentum factor in the Carhart model to gauge timing ability. We measure the stock selection and market timing of fund managers using these three baseline alternative measures.

\section{RESULTS AND DISCUSSION}

This section provides the empirical results exhibiting the presence of the stock selection skill and market timing ability among Indian fund managers, evaluating the performance of mutual fund managers using single and multifactor models. This study presents the result in Panels A (stock selection), Panel B (Market timing, TM) and Panel C (Market timing, HM) of Table 3. A significant positive $\boldsymbol{\alpha}^{\text {Carhart }}, \boldsymbol{\alpha}^{\mathrm{FF}}$ and $\boldsymbol{\alpha}^{\mathrm{CAPM}}$ denotes the stock selection, while positive and significant $Y_{i, t}$ represents market timing ability of the fund managers using TM and HM models, respectively (Panel B and C).The regression estimates presented in Table 3, indicate that the alpha estimates are positive and significant in single and multifactor models. The coefficients along with the Newey-West t-statistics (in parenthesis) are reported. $\alpha^{\mathrm{CAPM}}$ are positive and significant at 1 per cent level in all three Panels, while $\alpha^{\text {Carhart }}$ and $\alpha^{\mathrm{FF}}$ are positive significant at 10 per cent level in Panel A. 
This implies that the fund managers have stock selection skills. While timing coefficients $\left(Y_{i, t}\right)$ reported in Table 4.3 (Panel B and C) using TM and HM models are negative and insignificant indicating that Indian fund managers lack The table reports the descriptive statistics of the fund managers' performance evaluation. Panel A reports the stock selection skills while Panel B and C presents the market timing ability across CAPM andmultifactor models. Both the findings are in agreement with the previous studies carried out in the Indian context (Jayadev, 1998; Tripathy, 2006; Kumar 2012; Dhar \& Mandal, 2014). market timing ability proposed by TM and HM model, respectively.

Table 3

\begin{tabular}{|c|c|c|c|c|c|c|c|}
\hline Models & $\boldsymbol{\alpha}_{\mathrm{i}}$ & $\boldsymbol{\beta}_{\mathbf{i}}$ & $Y_{i t}$ & SMB & HML & WML & $\operatorname{Adj} R^{2}$ \\
\hline \multicolumn{8}{|c|}{ Panel A: Stock Selection } \\
\hline \multirow[t]{2}{*}{ Carhart } & $0.0013^{*}$ & $0.8725 * * *$ & -- & $0.1177 * * *$ & 0.0004 & 0.0021 & 0.97 \\
\hline & $(1.81)$ & $(87.24)$ & & $(8.23)$ & $(0.03)$ & $(0.17)$ & \\
\hline \multirow[t]{2}{*}{ Fama-French } & $0.0014^{*}$ & $0.8724 * * *$ & -- & $0.1174 * * *$ & 0.0002 & & 0.97 \\
\hline & (1.91) & (87.51) & & $(8.28)$ & $(0.02)$ & & \\
\hline \multirow[t]{2}{*}{ CAPM } & $0.0024 * * *$ & $0.8860^{* * *}$ & -- & & & & 0.96 \\
\hline & (3.04) & (81.11) & & & & & \\
\hline \multicolumn{8}{|c|}{ Panel B: Market timing (Treynor-Mazuy) } \\
\hline \multirow[t]{2}{*}{ Carhart } & 0.0014 & $0.8725 * * *$ & -0.0146 & $0.1175^{* * *}$ & 0.0005 & 0.0021 & 0.97 \\
\hline & $(1.75)$ & $(87.05)$ & $(-0.24)$ & $(8.19)$ & $(0.04)$ & $(0.17)$ & \\
\hline \multirow[t]{2}{*}{ Fama-French } & $0.0014^{*}$ & $0.8724^{* * *}$ & -0.0146 & $0.1173^{* * *}$ & 0.0004 & & 0.98 \\
\hline & $(1.83)$ & $(87.31)$ & $(-0.24)$ & $(8.24)$ & $(0.03)$ & & \\
\hline \multirow[t]{2}{*}{ CAPM } & $0.0026 * * *$ & $0.8861 * * *$ & -0.0343 & & & & 0.96 \\
\hline & $(2.96)$ & $(80.97)$ & $(-0.49)$ & & & & \\
\hline \multicolumn{8}{|c|}{ Panel C: Market timing (Henriksson-Merton) } \\
\hline \multirow[t]{2}{*}{ Carhart } & 0.0016 & $0.8777 * * *$ & -0.0104 & $0.1169 * * *$ & 0.0009 & 0.0019 & 0.98 \\
\hline & $(1.49)$ & $(50.03)$ & $(-0.36)$ & $(8.07)$ & $(0.07)$ & $(0.16)$ & \\
\hline \multirow[t]{2}{*}{ Fama-French } & 0.0017 & $0.8777 * * *$ & -0.0105 & $0.1167 * * *$ & 0.0007 & & 0.98 \\
\hline & $(1.56)$ & $(50.15)$ & $(-0.37)$ & $(8.12)$ & $(0.06)$ & & \\
\hline \multirow[t]{2}{*}{ CAPM } & $0.0035^{* * *}$ & $0.9064 * * *$ & -0.0406 & & & & 0.97 \\
\hline & $(2.97)$ & $(46.16)$ & $(-1.25)$ & & & & \\
\hline
\end{tabular}

Fund returns are averaged each month across funds and the resultant time series is regressed on the Jensen (1968), Fama and French (1993) and Carhart (1997) models. This table presents thefund managers stock selection and market timing ability. $\boldsymbol{\alpha}^{\text {Carhart }}, \boldsymbol{\alpha}^{\mathrm{FF}}$ and $\boldsymbol{\alpha}^{\mathrm{CAPM}}$ denotes the stock

The market return reported in the table is highly significant across various measures. The $\beta_{\mathrm{i}}$ coefficients are less than 1 and significant at implying that the fund managers are riskaverse and market portfolios are riskier. Among the factor, the SMB factor is positive and significant, while the HML and WML factors are not statistically significant.

\section{Sub-period test}

The sub-period results are contained in Table 4.The regression analysis indicates that sub-period results are consistent with the overall period. The alpha coefficients are positive and significant using CAPM model, however, the multifactor models generate positive yet insignificant alphas. The sub-period analysis provides little evidence of the presence of stock-picking skills among the fund managers. Whereas, the $Y_{i, t}$ coefficients are negative and selection while $\gamma_{\text {it }}$ represents market timing of the fund managers using TM and HM models, respectively. The regression results are exhibited in three Panels namely $\mathrm{A}, \mathrm{B}$ and $\mathrm{C}$. The t-statistics are in the parenthesis.***, **, * represents $1 \%, 5 \%$ \& $10 \%$ level of significance.

insignificant in sub-periods using single and multifactor models. Both the sub-periods, thus, failed to report any evidence of market timing ability of the fund managers across various measures employed. Overall, the sub-period analysis results are in line with the findings of previous studies that reported limited stock selection skills and lack any evidence of the presence of market timing ability among Indian fund managers across time and various measures employed.

The regression analysis of mutual fund managers' stock selection and market timing ability for each sub-set. Subperiod 1 covers the period from April 2000 to March 2009, while the sub-periods 2 from April 2009 to March 2018. 
Mutual Fund Performance: Evidence from India

Table 4

\begin{tabular}{|c|c|c|c|c|c|c|c|}
\hline Models & $\boldsymbol{\alpha}_{\mathrm{i}}$ & MKT & $\mathbf{Y}_{\mathrm{i}, \mathrm{t}}$ & SMB & HML & WML & Adj. $\mathbf{R}^{2}$ \\
\hline \multicolumn{8}{|c|}{ Sub-Period 1} \\
\hline \multicolumn{3}{|c|}{ Panel A: Stock selection } & & & & & \\
\hline \multirow[t]{2}{*}{ Carhart } & 0.0012 & $0.8608 * * *$ & -- & $0.1095 * * *$ & -0.0106 & 0.0096 & \\
\hline & $(0.93)$ & $(60.13)$ & -- & $(5.22)$ & $(-0.54)$ & $(0.57)$ & 0.95 \\
\hline \multirow[t]{2}{*}{ Fama-French } & 0.0013 & $0.8612 * * *$ & -- & $0.1075 * * *$ & -0.0093 & & \\
\hline & $(1.06)$ & $(60.43)$ & -- & $(5.22)$ & $(-0.48)$ & & 0.94 \\
\hline \multirow[t]{2}{*}{ CAPM } & 0.0019 & $0.8715 * * *$ & -- & & & & \\
\hline & $(1.40)$ & $(55.82)$ & -- & & & & 0.91 \\
\hline \multicolumn{8}{|c|}{ Panel B: Market timing (Treynor-Mazuy) } \\
\hline \multirow[t]{2}{*}{ Carhart } & 0.0021 & $0.8545 * * *$ & -0.1270 & $0.1084 * * *$ & -0.0111 & 0.0115 & \\
\hline & $(1.39)$ & $(55.47)$ & $(-1.10)$ & $(5.17)$ & $(-0.57)$ & $(0.68)$ & 0.94 \\
\hline \multirow[t]{2}{*}{ Fama-French } & 0.0022 & $0.8553 * * *$ & -0.1193 & $0.1061^{* *}$ & -0.0096 & & \\
\hline & $(1.46)$ & $(55.85)$ & $(-1.04)$ & $(2.14)$ & $(-0.50)$ & & 0.91 \\
\hline \multirow[t]{2}{*}{ CAPM } & $0.0031 *$ & $0.8633 * * *$ & -0.1612 & & & & \\
\hline & $(1.88)$ & $(51.24)$ & $(-1.27)$ & & & & 0.90 \\
\hline \multicolumn{8}{|c|}{ Panel C: Market timing (Henriksson-Merton) } \\
\hline \multirow[t]{2}{*}{ Carhart } & 0.0026 & $0.8786^{* * *}$ & -0.0420 & $0.1077 * * *$ & -0.0107 & 0.0108 & \\
\hline & $(1.26)$ & $(35.15)$ & $(-0.87)$ & $(5.10)$ & $(-0.55)$ & $(0.63)$ & 0.94 \\
\hline \multirow[t]{2}{*}{ Fama-French } & 0.0027 & $0.8781^{* * *}$ & -0.0397 & $0.1056 * * *$ & -0.0094 & & \\
\hline & $(1.30)$ & $(35.25)$ & $(-0.83)$ & $(5.08)$ & $(-0.49)$ & & 0.90 \\
\hline \multirow[t]{2}{*}{ CAPM } & $0.0042^{*}$ & $0.9002 * * *$ & -0.0683 & & & & \\
\hline & $(1.87)$ & $(33.14)$ & $(-1.29)$ & & & & 0.89 \\
\hline \multicolumn{8}{|c|}{ Sub-Period 2} \\
\hline \multicolumn{8}{|c|}{ Panel A: Stock selection } \\
\hline \multirow[t]{2}{*}{ Carhart } & 0.0011 & $0.8912 * * *$ & -- & $0.1473 * * *$ & 0.0159 & 0.0062 & \\
\hline & $(1.46)$ & $(61.56)$ & -- & $(7.76)$ & $(0.84)$ & $(0.30)$ & 0.97 \\
\hline \multirow[t]{2}{*}{ Fama-French } & 0.0012 & $0.8908 * * *$ & -- & $0.1470 * * *$ & 0.0133 & & \\
\hline & $(1.63)$ & $(62.12)$ & -- & (7.79) & $(0.80)$ & & 0.95 \\
\hline \multirow[t]{2}{*}{ CAPM } & $0.0028 * * *$ & $0.9163^{* * *}$ & -- & & & & \\
\hline & $(3.22)$ & $(61.62)$ & -- & & & & 0.92 \\
\hline \multicolumn{8}{|c|}{ Panel B: Market timing (Treynor-Mazuy) } \\
\hline \multirow[t]{2}{*}{ Carhart } & 0.0013 & $0.8996 * * *$ & -0.0613 & $0.1474 * * *$ & 0.0122 & 0.0055 & \\
\hline & $(1.60)$ & (49.18) & $(-0.75)$ & $(7.75)$ & $(0.63)$ & $(0.27)$ & 0.98 \\
\hline \multirow[t]{2}{*}{ Fama-French } & 0.0013 & $0.8993 * * *$ & -0.0624 & $0.1472 * * *$ & 0.0098 & & \\
\hline & $(1.77)$ & $(49.45)$ & $(-0.77)$ & (7.78) & $(0.57)$ & & 0.97 \\
\hline \multirow[t]{2}{*}{ CAPM } & $0.0030 * * *$ & $0.9244 * * *$ & -0.0724 & & & & \\
\hline & $(3.30)$ & $(49.88)$ & $(-0.74)$ & & & & 0.91 \\
\hline Panel C: Mark & ning (Henrikss & on-Merton) & & & & & \\
\hline Carhart & 0.0015 & $0.9029 * * *$ & -0.0166 & $0.1458 * * *$ & 0.0146 & 0.0045 & \\
\hline & $(1.28)$ & $(28.40)$ & $(-0.41)$ & $(7.50)$ & $(0.76)$ & $(0.21)$ & 0.98 \\
\hline Fama-French & 0.0016 & $0.9038 * * *$ & -0.0183 & $0.1454 * * *$ & 0.0126 & & \\
\hline & $(1.45)$ & $(28.80)$ & $(-0.47)$ & (7.55) & $(0.75)$ & & 0.97 \\
\hline CAPM & $0.0042 * * *$ & $0.9673 * * *$ & -0.0748 & & & & \\
\hline & (3.38) & $(27.14)$ & $(-1.57)$ & & & & 0.91 \\
\hline $\begin{array}{l}\text { The parenthe } \\
\text { significant at } \\
\text { respectively. }\end{array}$ & $\begin{array}{l}\text { xhibits the t- } \\
5 \% \text { and } 10^{\circ}\end{array}$ & $\begin{array}{l}\text { statistics of th } \\
\text { o denoted by }\end{array}$ & $\begin{array}{l}\text { e regression } \\
* * *, * *, *\end{array}$ & $\begin{array}{lr}\text { Stock } & \text { selec } \\
\text { timing } & (e \\
\text { period }) & \end{array}$ & $\begin{array}{l}\text { on and ma } \\
\text { cluding }\end{array}$ & & \\
\hline $\begin{array}{l}\text { Retrieval Nun } \\
\text { DOI:10.3594 } \\
\text { Journal Webs }\end{array}$ & $\begin{array}{l}\text { D4284118419/201 } \\
. \text { D4284.118419 } \\
\text { ww.ijrte.org }\end{array}$ & $9 @ B E I E S P$ & 117 & $\begin{array}{l}\text { Published } \\
\text { Blue Eyes } \\
\text { \& Sciences }\end{array}$ & $\begin{array}{l}\text { ntelligence Engin } \\
\text { Publication }\end{array}$ & ering & \\
\hline
\end{tabular}


To check the robustness of our results to ensure that the result presented earlier in Table 3 is not driven by the global financial crisis of 2008, we exclude the data from January 2008 to December 2009. We rerun the regression on the data excluding crisis period to examine the stock selection and Stock selection and market timing (excluding global financial crisis period) market timing ability of fund managers presented in Table 5. In comparison with the previous results reported in Table 3, the evidence of stock timing is slightly weaker but still significant with the absence of market timing ability excluding the global financial crisis of 2008-09.

Table 5

\begin{tabular}{|c|c|c|c|c|c|c|c|}
\hline Models & $\boldsymbol{\alpha}_{\mathrm{i}}$ & $\boldsymbol{\beta}_{\mathbf{i}}$ & $Y_{i, t}$ & SMB & HML & WML & $\operatorname{Adj} R^{2}$ \\
\hline \multicolumn{8}{|c|}{ Panel A: Stock selection } \\
\hline \multirow[t]{2}{*}{ Carhart } & $0.0017 * *$ & $0.8709 * * *$ & $\begin{array}{ll}- \\
-\end{array}$ & $0.1126^{* * *}$ & 0.0003 & -0.0006 & \\
\hline & $(2.10)$ & (69.98) & $\begin{array}{ll}-- \\
\end{array}$ & (7.57) & $(0.02)$ & $(-0.04)$ & 0.96 \\
\hline \multirow[t]{2}{*}{ Fama French } & $0.0017 * *$ & $0.8709 * * *$ & -- & $0.1127 * * *$ & 0.0004 & & \\
\hline & (2.17) & $(70.26)$ & -- & (7.64) & $(0.03)$ & & 0.96 \\
\hline \multirow[t]{2}{*}{ CAPM } & 0.0028 & $0.8823 * * *$ & -- & & & & \\
\hline & (3.29) & (64.99) & -- & & & & 0.95 \\
\hline \multicolumn{8}{|c|}{ Panel B: Market timing (Treynor-Mazuy) } \\
\hline \multirow[t]{2}{*}{ Carhart } & $0.0016^{*}$ & $0.8709 * * *$ & 0.0174 & $0.1130 * * *$ & 0.0000 & -0.0007 & \\
\hline & $(1.75)$ & (69.76) & $(0.15)$ & $(7.48)$ & $(0.00)$ & $(-0.06)$ & 0.96 \\
\hline \multirow[t]{2}{*}{ Fama French } & $0.0016^{*}$ & $0.8710^{* * *}$ & 0.0169 & $0.1130^{* * *}$ & 0.0001 & & \\
\hline & $(1.77)$ & (70.04) & $(0.14)$ & $(7.54)$ & $(0.01)$ & & 0.96 \\
\hline \multirow[t]{2}{*}{ CAPM } & $0.0032 * * *$ & $0.8821 * * *$ & -0.1074 & & & & \\
\hline & $(3.23)$ & $(64.91)$ & $(-0.82)$ & & & & 0.95 \\
\hline \multicolumn{8}{|c|}{ Panel C: Market timing (Henriksson-Merton) } \\
\hline \multirow[t]{2}{*}{ Carhart } & 0.0014 & $0.8658 * * *$ & 0.0100 & $0.1134 * * *$ & -0.0003 & -0.0006 & \\
\hline & $(1.16)$ & $(37.14)$ & $(0.26)$ & $(7.44)$ & $(-0.02)$ & $(-0.05)$ & 0.97 \\
\hline \multirow[t]{2}{*}{ Fama French } & 0.0014 & $0.8658 * * *$ & 0.0099 & $0.1135^{* * *}$ & -0.0002 & & \\
\hline & (1.17) & (37.27) & $(0.26)$ & (7.50) & $(-0.02)$ & & 0.97 \\
\hline \multirow[t]{2}{*}{ CAPM } & $0.0038^{* * *}$ & $0.9043^{* * *}$ & -0.0425 & & & & \\
\hline & $(2.87)$ & (34.93) & $(-1.00)$ & & & & 0.95 \\
\hline
\end{tabular}

The parenthesis exhibits the t-statistics of the regression significant at $1 \%, 5 \%$ and $10 \%$ denoted by $* * *, * *, *$, respectively.

For the robustness check of the results, we examine the fund-level analysis of the stock selection and market timing ability. Table 6 presents the t-statistics of each fund to distributed cross-sectionally to determine the significant stock selection and market timing abilities using the Carhart model across individual funds. The fund level analysis provides meaningful insights concerning stock selection and market timing abilities of the fund managers. Column 5-10 in Table 6 presents the t-statistics distribution and timing coefficients exceeding the indicated values. The table exhibits that out of 183 funds, 121 funds (about 65 per cent) are positive and 39 funds (21 per cent) are able to generate significant alphas.The fund level analysis of TM (HM) return timing states that 18 per cent (13.2 per cent) of the sample funds have t-statistics smaller than -1.645 and about 10.4 per cent (11.5 per cent) of the funds have t-statistics greater than 1.645, which suggests that the left tails are slightly thicker than the right tails. ). In general, the fund level analysis provides little evidence of stock selection skills but failed to report any market timing ability among Indian fund managers. These results are in line with the previous studies that report the presence of selectivity skills but lack timing abilities (Deb et al., 2007; Panda et al., 2015).

\section{CONCLUSION}

We investigate the stock selection and market timing ability of mutual fund managers in India covering the period of April 2000 to March 2018, using CAPM, Fama-French and Carhart multifactor models. Our empirical evidence suggests that fund managers exhibit positive and significant stock selection ability measured using single and multifactor models, but only for a relatively small number of equity funds.

Published By:

Blue Eyes Intelligence Engineering \& Sciences Publication 


\section{Mutual Fund Performance: Evidence from India}

On the other hand, both variants of the performance measures (TM and HM) provide a lack of evidence of market timing ability of fund managers.Among the three benchmark models, CAPM measure provides the highest magnitude and statistically significant coefficients at the 1 per cent level in stock selection ability. The market timing, however, shows negative and insignificant timing coefficients. The sub-period analysis results report limited stock selection skills as only CAPM measure provide positive and significant alphas. The multifactor models suggest that fund managers don't possess stock selection skills and lack any evidence of the presence of market timing ability among Indian fund managers. The results are robust with respect to alternative measures and period of analysis and even at the fund level. Moreover, the exclusion The table presents descriptive statistics of individual fund stock selection and market timing ability using Carhart (1997) model. of the crisis period from the analysis didn't alter the results. The findings of this paper are in consonance with studies in the Indian context. In conclusion, it can be said that the Indian fund managers exhibit some stock selection skills but lack in market timing ability. The above findings imply that active portfolio management may not yield superior returns in comparison to a passive investment strategy for Indian investors. The robustness of the results can be evaluated using different benchmarks. Further, alternative measures of return calculation, such as holding based measure can be used to reexamine the mutual fund performance. Moreover, conditional models and the use of other factors such as liquidity timing and co-skewness in benchmark models can be utilized to provide fresh insights regarding mutual fund performance in India.

Table 6

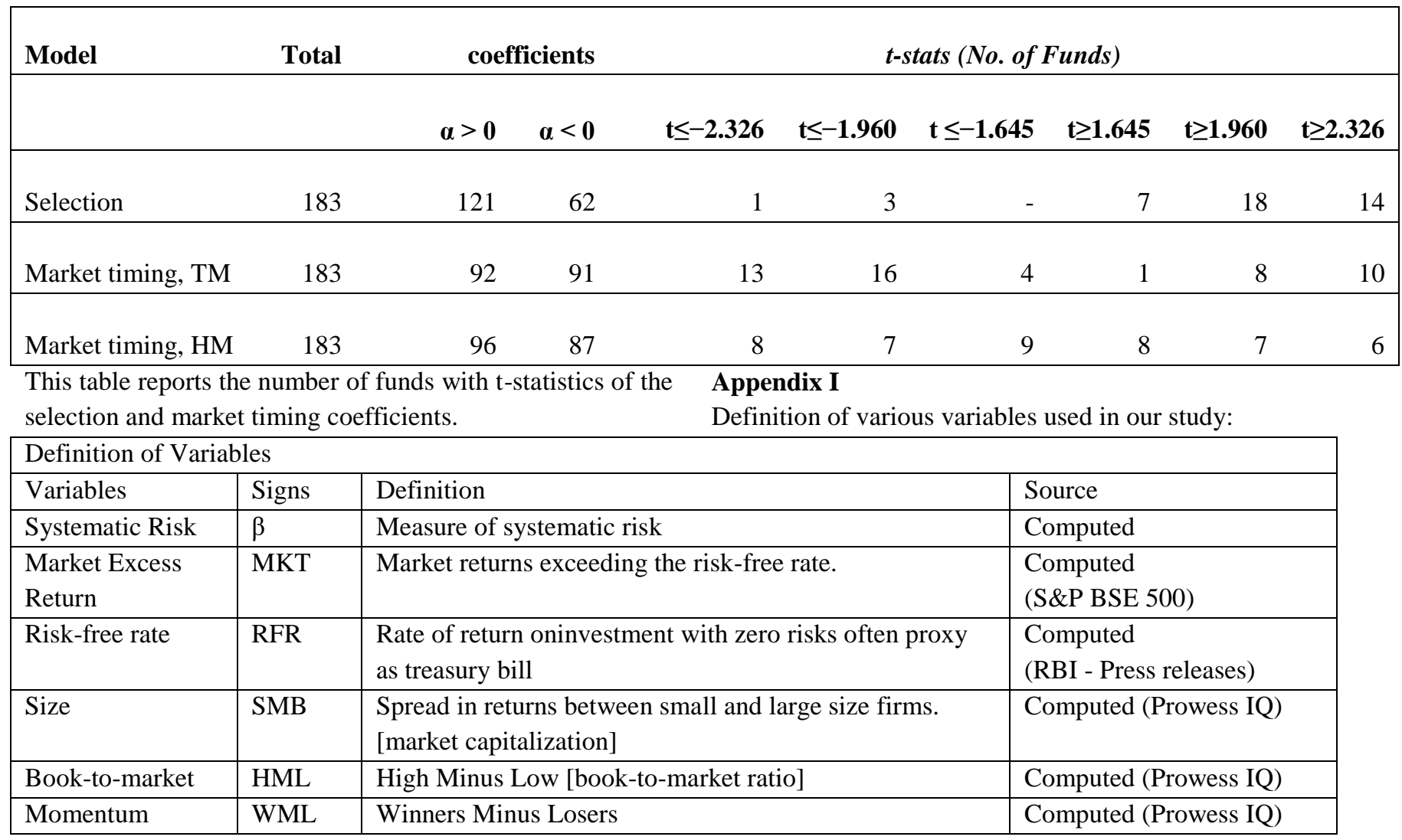

\section{Appendix II}

The calculation of $\mathrm{SMB}_{\mathrm{t}}$ (size factor), HML (book to $_{\mathrm{t}}$ market factor), and $\mathrm{WML}_{\mathbf{t}}$ (momentum factor) in India:

Following Fama and French (1993), we use $t=i-1$ yearend market capitalization of the firms and $\mathrm{B} / \mathrm{M}$ (book to market value ratio) in September in $t=i$ to classify all stocks in S\&P BSE 500 index. We have $3 \times 2$ matrices formed on the basis of high, neutral, and low firm size (market capitalization) and $\mathrm{B} / \mathrm{M}$ ratios. The growth $(\mathrm{G})$, neutral $(\mathrm{N})$, and value $(\mathrm{V}) \mathrm{B} / \mathrm{M}$ classification is based on top $30 \%$, neutral $40 \%$, and bottom $30 \%$ of $\mathrm{B} / \mathrm{M}$ ratios, respectively. For firm size, we have taken the median of maket capitalization of each stock to demarcate the above as the Big (B) and below the median as small (S). Then, we form $(2 * 3)$ six portfolios for October in $t=i$ to September in $\mathrm{t}=\mathrm{i}+1$. These six portfolios are named as SG, SN, SV, BG, $\mathrm{BN}, \mathrm{BV}$. For instance, the lowest $30 \%$ in the portfolio formed by stocks of the book-to-market value ratios and the largest $50 \%$ of the firm size is termed as SG. We calculate the monthly equal-weighted and value-weighted (market) returns from these six portfolios and labelled as SG, SN, SV, $\mathrm{BG}, \mathrm{BN}, \mathrm{BV}$. Thus, $\mathrm{SMB}_{\mathrm{t}}=\frac{1}{3}(\mathrm{SG}+\mathrm{SN}+\mathrm{SV})-\frac{1}{3}$ $(\mathrm{BG}+\mathrm{BN}+\mathrm{BV})$ 
Specifically, $\mathrm{HML}_{\mathrm{T}}=\frac{1}{2}(\mathrm{SV}+\mathrm{BV})-\frac{1}{2}(\mathrm{SG}+\mathrm{BG})$

Similarly, we follow the Carhart (1997) to construct the momentum factor. At month $\mathrm{t}$, we calculate the holding period of A-share stocks from $\mathrm{t}-12, \mathrm{t}-2$, and sort from the highest to the lowest (top 30\% - bottom 30\%) valueweighted returns.

\section{REFERENCES:}

1. Admati, A. R., Bhattacharya, S., Pfleiderer, P., \& Ross, S. A. (1986) On timing and selectivity. The Journal of Finance, 41(3), 715-730.

2. Agarwal, P. K., \& Pradhan, H. K. (2018). Mutual Fund Performance Using Unconditional Multifactor Models: Evidence from India. Journal of Emerging Market Finance, 17(2_suppl), S157-S184.

3. Agrawal, D. (2011). Measuring performance of Indian mutual funds. Finance India, June.

4. Ahmad, M., \& Samajpati, U. (2010). Evaluation of stock selection skills and market timing abilities of Indian mutual fund managers. Management Insight, 6(2).

5. Angelidis, T., Giamouridis, D., \& Tessaromatis, N. (2013). Revisiting mutual fund performance evaluation. Journal of Banking \& Finance, 37(5), 1759-1776.

6. Babalos, V., Philippas, N., Doumpos, M., \& Zopounidis, C. (2012). Mutual funds performance appraisal using stochastic multicriteria acceptability analysis. Applied Mathematics and Computation, 218(9), 5693-5703.

7. Barras, L., Scaillet, O., \& Wermers, R. (2010). False discoveries in mutual fund performance: Measuring luck in estimated alphas. The journal of finance, 65(1), 179-216.

8. Black, F., Jensen, M. C., \& Scholes, M. (1972). The capital asset pricing model: Some empirical tests. Studies in the theory of capital markets, 81(3), 79-121.

9. Bodson, L., Cavenaile, L., \& Sougné, D. (2013). A global approach to mutual funds market timing ability. Journal of Empirical Finance, 20, 96-101.

10. Bollen, N. P., \& Busse, J. A. (2001). On the timing ability of mutual fund managers. The Journal of Finance, 56(3), 1075-1094.

11. Cao, C., Simin, T. T., \& Wang, Y. (2013). Do mutual fund managers time market liquidity?. Journal of Financial Markets, 16(2), 279-307.

12. Carhart, M. M. (1997). On persistence in mutual fund performance. The Journal of finance, 52(1), 57-82.

13. Chang, E. C., \& Lewellen, W. G. (1984). Market timing and mutual fund investment performance. Journal of Business, 57-72.

14. Chen, D., Gan, C., \& Hu, B. (2013). An empirical study of mutual funds performance in China. Available at SSRN 2220323.

15. Cuthbertson, K., Nitzsche, D., \& O'Sullivan, N. (2012). False discoveries in UK mutual fund performance. European Financial Management, 18(3), 444-463.

16. Daniel, K., Grinblatt, M., Titman, S., \& Wermers, R. (1997). Measuring mutual fund performance with characteristic-based benchmarks. The Journal of finance, 52(3), 1035-1058.

17. Deb, S. G., Banerjee, A., \& Chakrabarti, B. B. (2007). Market timing and stock selection ability of mutual funds in India: an empirical investigation. Vikalpa, 32(2), 39-52.

18. Dhar, J., \& Mandal, K. (2014). Market timing abilities of Indian mutual fund managers: An empirical analysis. Decision, 41(3), 299311.

19. Elton, E. J., Gruber, M. J., \& Blake, C. R. (1996). The persistence of risk-adjusted mutual fund performance. Journal of business, 133-157.

20. Elton, E. J., Gruber, M. J., \& Blake, C. R. (2011). An examination of mutual fund timing ability using monthly holdings data. Review of Finance, 16(3), 619-645.

21. Fama, E. F. (1972). Components of investment performance. The Journal of Finance, 27(3), 551-568.

22. Fama, E. F., \& French, K. R. (1993). Common risk factors in the returns on stocks and bonds. Journal of financial economics, 33(1), 356.

Retrieval Number: D4284118419/2019@BEIESP

DOI:10.35940/ijrte.D4284.118419

Journal Website: www.ijrte.org
23. Fama, E. F., \& French, K. R. (2010). Luck versus skill in the cross-section of mutual fund returns. The journal of finance, 65(5), 1915-1947.

24. Feng, X., Zhou, M., \& Chan, K. C. (2014). Smart money or dumb money? A study on the selection ability of mutual fund investors in China. The North American Journal of Economics and Finance, 30, 154-170.

25. Ferson, W. E., \& Schadt, R. W. (1996). Measuring fund strategy and performance in changing economic conditions. The Journal of finance, 51(2), 425-461.

26. Ferson, W., \& Mo, H. (2016). Performance measurement with selectivity, market and volatility timing. Journal of Financial Economics, 121(1), 93-110.

27. Grinblatt, M., \& Titman, S. (1989). Mutual fund performance: An analysis of quarterly portfolio holdings. Journal of business, 393-416.

28. Grinblatt, M., \& Titman, S. (1992). The persistence of mutual fund performance. The Journal of Finance, 47(5), 1977-1984.

29. Gupta, O. P., \& Sehgal, S. (1998, December). Investment performance of mutual funds: the Indian experience. In Second UTIICM Capital Markets Conference.

30. Hendricks, D., Patel, J., \& Zeckhauser, R. (1993). Hot hands in mutual funds: Short-run persistence of relative performance, 19741988. The Journal of finance, 48(1), 93-130.

31. Henriksson, R. D. (1984). Market timing and mutual fund performance: An empirical investigation. Journal of Business, 73-96.

32. Henriksson, R. D., \& Merton, R. C. (1981). On market timing and investment performance. II. Statistical procedures for evaluating forecasting skills. Journal of Business, 513-533.

33. Jayadev, M. (1998). Performance evaluation of portfolio managers: An empirical evidence on Indian mutual funds. Applied Finance, 5(2), 41-67.

34. Jensen, M. C. (1968). The performance of mutual funds in the period 1945-1964. The Journal of Finance, 23(2), 389-416.

35. Jiang, G. J., Yao, T., \& Yu, T. (2007). Do mutual funds time the market? Evidence from portfolio holdings. Journal of Financial Economics, 86(3), 724-758.

36. Jiang, W. (2003). A nonparametric test of market timing. Journal of Empirical Finance, 10(4), 399-425.

37. Kao, G. W., Cheng, L. T., \& Chan, K. C. (1998). International mutual fund selectivity and market timing during up and down-market conditions. Financial Review, 33(2), 127-144.

38. Kon, S. J. (1983). The market-timing performance of mutual fund managers. Journal of Business, 323-347.

39. Kumar, R. (2012). Market timing, selectivity and mutual fund performance: an empirical investigation of selective equity diversified schemes in India.UP Journal of Financial Economics, 10(1), 62.

40. Kundu, A. (2009). Stock selection performance of mutual fund managers in India: An empirical study. Journal of Business and Economic Issues, 1(1), 59-73.

41. Lee, C. F., \& Rahman, S. (1990). Market timing, selectivity, and mutual fund performance: An empirical investigation. The Journal of Business, 63(2), 261-278.

42. Matallin-Saez, J. C. (2008). The dynamics of mutual funds and market timing measurement. Studies in Nonlinear Dynamics \& Econometrics, 12(4)

43. Nathani, N., Chakraborty, A., Rawat, B., \& Holani, U. (2011). Timing skills of fund managers: a study of equity mutual fund schemes. Journal of Business Spectrum, 1(1), 9-18.

44. Neto, N. M. V., Lobão, J. F. S. S. D. M., \& Vieira, E. S. (2017). Do Portuguese mutual funds displayforecasting skills? A study on selectivity and market timing ability. Studies in Economics and Finance, 34(4), 597-631.

45. Oliveira, L., Salen, T., Curto, J. D., \& Ferreira, N. (2019). Market timing and selectivity: an empirical investigation of European mutual fund performance. Market timing and selectivity: an empirical investigation of European mutual fund performance, (2).

46. Panda, B., Mahapatra, R. P., \& Moharana, S. (2015). Myth of equity mutual fund performance. Vision, 19(3), 200 209.

Published By:

Blue Eyes Intelligence Engineering \& Sciences Publication 


\section{Mutual Fund Performance: Evidence from India}

47. Philippas, N. (2002). Market timing and selectivity: an empirical investigation into the features of Greek mutual fund managers. Journal of Applied Business Research, 18(3), 97-108.

48. Rao, S. U. (2000). Market timing and mutual fund performance. American Business Review, 18(2), 75.

49. Romacho, J. C., \& Cortez, M. C. (2006). Timing and selectivity in Portuguese mutual fund performance. Research in International Business and Finance, 20(3), 348-368.

50. Roy, B., \& Deb, S. S. (2004). Conditional alpha and performance persistence for Indian mutual funds: empirical evidence. ICFAI Journal of applied finance, 30-48.

51. Sharpe, W. F. (1966). Mutual fund performance. The Journal of business, 39(1), 119-138.

52. Treynor, J. L. (1965). How to rate management of investment funds. Harvard business review, 43(1), 63-75.

53. Treynor, J., \& Mazuy, K. (1966). Can mutual funds outguess the market? Harvard Business Review, 44(4), 131-136.

54. Tripathy, N. P. (2006). Market Timing Abilities and Mutual Fund Performance: An Empirical Investigation into Equity Linked Saving Schemes. Vilakshan, XIMB journal of Management, 3(2), 127-138.

55. Ünal, G., \& Tan, Ö. F. (2015). Selectivity and Market Timing Ability of Polish Fund Managers Analysis of Selected Equity Funds. Procedia-Social and Behavioral Sciences, 213, 411-416.

56. Yi, L., \& He, L. (2016). False discoveries in style timing of Chinese mutual funds. Pacific-Basin Finance Journal, 38, 194-208.

57. Zheng, L. (1999). Is money smart? A study of mutual fund investors' fund selection ability. The Journal of Finance, 54(3), 901-933.

\section{AUTHOR'S PROFILE}

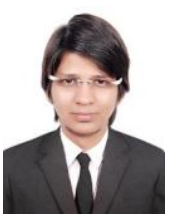

Mahfooz Alam is a research scholar pursuing his $\mathrm{PhD}$ in Finance in the department of Business Administration, Faculty of Management Studies and Research, Aligarh Muslim University, India. His research interest includes financial markets, mutual funds, asset pricing and Islamic Banking.He has published paper in international journal of repute. 